\title{
Ewolucyjna Teleonomia jako zasada unifikująca Rozszerzonej Syntezy Ewolucyjnej *
}

\section{Wprowadzenie}

Zasady unifikujące zajmują ważne miejsce nie tylko w biologii, ale i we wszystkich naukach. Dostarczają domyślnego sposobu postrzegania świata. Głównym celem zasad unifikujących, w odróżnieniu od ścisłych praw, jest zapewnienie badaczom mapy mentalnej badanego przez nich obszaru. Prawa wyznaczają nienaruszalne warunki, a zasady unifikujące - uogólnienia, które można bezpiecznie stosować, gdy brak przeczących im danych empirycznych. Badacze posługują się zasadami unifikującymi niejawnie, kiedy przyjmują upraszczające założenia, wstępne wnioski i kierunki badań.

Przykładowo lokalność stanowi zasadę unifikującą w fizyce. W tej dziedzinie nauki powszechnie zakłada się, że czynniki przyczynowe znajdujące się blisko jakiegoś zdarzenia zasadniczo wywierają na nie odpowiednio większy org. Genezy.

(C) Copyright by Jonathan Bartlett, BIO-Complexity, Dariusz Sagan \& Filozoficzne Aspekty

* Jonathan BartLett, „Evolutionary Teleonomy as a Unifying Principle for the Extended Evolutionary Synthesis", BIO-Complexity 2017, no. 2, s. 1-7, http://bio-complexity.org/ojs/index. php/main/article/view/BIO-C.2017.2/BIO-C.2017.2 (02.10.2018). Za zgodą Autora z języka angielskiego przełożył: Dariusz SAGAN. 
wpływ niż czynniki przyczynowe bardziej od niego odległe. Zasada ta nie jest uznawana za prawo - wiemy wręcz, że w wielu przypadkach jest ona fałszywa. Jest to jednak zasada unifikująca. Gdy badacze dostrzegają osobliwe zjawisko, nie sprawdzają w pierwszej kolejności, czy na przebieg eksperymentu w laboratorium wpływają warunki panujące na Neptunie. Ich pierwszą reakcją jest sprawdzenie, czy zjawisko to powodowane jest przez jakieś nieodległe warunki.

W zgodzie z daną zasadą unifikującą mogą być też tworzone nowe teorie lub przekształceniu mogą ulec teorie dotychczasowe. Początkowo trudno było pojąć grawitację w ramach zasady lokalności, ale problem ten rozwiązano dzięki nowemu ujęciu grawitacji jako zakrzywienia czasoprzestrzeni.

Wszyscy potrzebują mentalnej mapy obszaru, który badają. Istnieje nieskończona liczba dostępnych faktów, możliwych eksperymentów i sposobów rozumienia wyników. Zasady unifikujące, zarówno jawne, jak i niejawne, oferują mapę i drogowskazy nadające wysiłkom naukowców zrozumiałe (i przy odrobinie szczęścia właściwe) kierunki. Stanowią również źródło modeli zerowych wykorzystywanych przy testowaniu innych hipotez. ${ }^{1}$

Zasady unifikujące są pomocne także w nauczaniu. Nie można oczekiwać od studentów, że zapoznają się pośrednio lub bezpośrednio z całym materiałem źródłowym poprzedniego pokolenia, ale dobrze wyartykułowane zasady unifikujące pomagają zsyntetyzować wyniki wcześniejszych badań, nadając im zrozumiałą i sprawdzalną postać.

Zasady unifikujące spełniają większość swoich zadań bez trudu. Jest to korzystne, ponieważ jawne uzasadnienie każdego mentalnego kroku pochłaniałoby wiele czasu i energii. Zasady unifikujące należy jednak poddawać od czasu do czasu ponownej ocenie, aby upewnić się, że prowadzą nas w dobrym kierunku. Identyfikacja problematycznych zasad stanowi ważne zadanie, ponieważ dzięki temu przyszli badacze nie będą posiłkować się mentalną mapą, która nie odpowiada rzeczywistości.

\footnotetext{
${ }^{1}$ Por. Lindell Bromнam, „Does Nothing in Evolution Make Sense Except in the Light of Population Genetics?", Biology and Philosophy 2009, vol. 24, s. 387-403, doi:10.1007/s10539-0089146-6.
} 


\section{Nowoczesna Synteza}

Od lat dwudziestych do lat sześćdziesiątych dwudziestego wieku grupa naukowców formułowała zespół zasad unifikujących teorii ewolucji. Idee te, nazywane zbiorczo Nowoczesną Syntezą, wciąż stanowią układ odniesienia dla współczesnej biologii ewolucyjnej. Na jądro Nowoczesnej Syntezy składają się następujące idee:

1. Ewolucja na wszystkich poziomach jest wynikiem ciągłych zmian w populacjach opisywanych przez genetykę populacyjną. ${ }^{2}$

2. Mutacja genetyczna jest skutkiem procesów przypadkowych, takich jak błędy w replikacji DNA lub wpływ kosmicznego promieniowania rentgenowskiego. Innymi słowy, żaden proces lub układ kontrolny nie kieruje mutacją tak, by była korzystna dla organizmu. ${ }^{3}$

3. Głównym, nadającym ukierunkowanie czynnikiem wpływającym na ewolucję organizmów jest dobór naturalny, który również jest niezależny od jakiegokolwiek procesu czy układu kontrolnego. ${ }^{4}$

Należy zauważyć, że chociaż wielu ludzi sądzi, iż neutralna teoria ewolucji molekularnej ${ }^{5}$ jest niezgodna z Nowoczesną Syntezą, teoria ta w istocie zawiera w sobie główne jej cechy. Teoria neutralna (a) opiera się na genetyce populacyjnej, (b) nie postuluje żadnego kierowanego procesu powstawania mutacji i (c) utrzymuje, że jeśli w procesie ewolucji istnieje jakiś czynnik kierujący, to związane jest to z selekcją, ale samą selekcją nie kieruje żaden mechanizm. Podstawowa różnica między teorią neutralną a Nowoczesną Syntezą polega na tym, że

\footnotetext{
${ }^{2}$ Por. Douglas J. Futuyma, „Can Modern Evolutionary Theory Explain Macroevolution?”, w: Emanuele Serrelli and Nathalie Gontier (eds.), Macroevolution: Explanation, Interpretation and Evidence, Springer, New York 2015, s. 29-86, doi:10.1007/978-3-319-15045-1_2.

${ }^{3}$ Por. Francesca Merlin, „Evolutionary Chance Mutation: A Defense of the Modern Synthesis' Consensus View", Philosophy and Theory in Biology 2010, vol. 2, e103, doi:10.3998/ptb. 6959004.0002.003.

${ }^{4}$ Por. MerLin, „Evolutionary Chance Mutation...”.

${ }^{5}$ Por. Motoo Kimura, The Neutral Theory of Molecular Evolution, Cambridge University Press, Cambridge 1983.
} 
ta pierwsza - wbrew adaptacjonizmowi czy selekcjonizmowi — bagatelizuje znaczenie i konieczność selekcji jako czynnika kierującego, a w zamian kładzie nacisk na dominację zdarzeń stochastycznych w toku ewolucji.

Mimo że wspomniane wyżej zasady Nowoczesnej Syntezy nie są utrzymywane przez każdego biologa, uznawane są przez większość z nich. Traktowane są więc jako domyślne podejście do badań w ramach biologii ewolucyjnej.

\section{Rozszerzona Synteza Ewolucyjna}

Pewna luźno powiązana grupa biologów nawoływała przez ostatnie dziesięć lat do stworzenia nowej syntezy, która zastąpiłaby Nowoczesną Syntezę. Proponowany przez nich nowy sposób myślenia, nazywany obecnie Rozszerzona Synteza Ewolucyjna, zyskał na znaczeniu za sprawą warsztatów przeprowadzonych w 2008 roku w Konrad Lorenz Institute for Evolution and Cognition Research. Owocem tych warsztatów jest książka zatytułowana Evolution, the Extended Synthesis [Ewolucja, rozszerzona synteza]. ${ }^{6}$

Pośród nowych idei (niewystępujących w Nowoczesnej Syntezie) znajdują się następujące (według opisu Massimo Pigliucciego i Gerda Müllera ${ }^{7}$ ):

- Przygodność jako bardziej podstawowy czynnik determinujący możliwe mutacje.

- Zmiana nacisku $\mathrm{z}$ indywidualnych genów na sieci genów.

- Rozmaite nowe rodzaje dziedziczenia, w tym transpokoleniowe dziedziczenie epigenetyczne, dziedziczenie nisz i dziedziczenie kulturowe.

- Wpływ biologii rozwoju na teorię ewolucji.

- Analiza samej ewoluowalności.

Później do dyskusji dołączyło się wielu innych naukowców. Niektórzy

${ }^{6}$ Por. Massimo Pigliucci and Gerd B. Müller (eds.), Evolution, the Extended Synthesis, MIT Press, Cambridge 2010, doi:10.7551/mitpress/9780262513678.001.0001.

${ }^{7}$ Por. Massimo Pigluucci and Gerd B. Müller, „Elements of an Extended Evolutionary Synthesis”, w: Pigliucci and Müller (eds.), Evolution, the Extended Synthesis..., s. 3-17, doi: 10.7551/mitpress/9780262513678.003.0001. 
twierdzili, że nowa synteza jest absolutnie konieczna, ${ }^{8}$ inni, że Nowoczesna Synteza ma się dobrze, ${ }^{9}$ a jeszcze inni, że nie widzą między nimi różnicy.

Kevin Laland i współautorzy ${ }^{10}$ wymieniają cechy, które według nich świadczą o odrębności Rozszerzonej Syntezy Ewolucyjnej, mianowicie:

1. Rozszerzona dziedziczność: organizmy dziedziczą coś więcej niż tylko geny i dzięki czemuś więcej niż tylko dziedziczności fizycznej. U organizmów występuje nie tylko dziedziczność genetyczna i epigenetyczna, lecz również dziedziczność zachowania, której podstawą jest wychowanie przez rodziców i społeczności biologiczne.

2. Dwustronna przyczynowość: organizmy kształtują swoje środowisko, które następnie oddziałuje na nie same.

3. Nielosowa zmienność fenotypowa: organizmy mają tendencję do obierania pewnych kierunków ewolucji częściej niż innych, o czym świadczą istniejące fenotypy ewolucyjne.

4. Zmienne tempo zmiany: skutki mutacji są nieliniowe, a tym samym mogą mieć charakter skokowy.

5. Perspektywa organizmocentryczna: same organizmy odgrywają w Rozszerzonej Syntezie Ewolucyjnej większą rolę przyczynową niż w przyjmowanym w ramach Nowoczesnej Syntezy podejściu genocentrycznym.

6. Procesy makroewolucyjne: dodatkowe tryby dziedziczenia prowadzą również do dodatkowych procesów makroewolucyjnych.

Powyższa lista świadczy o ostrożnym podejściu przyjmowanym zwykle

${ }^{8}$ Por. Kevin N. Laland, Tobias Uller, Marc W. Feldman, Kim Sterelny, Gerd B. Müller, Armin MoczeK, Eva Jablonka, and John Odling-Smee, „Does Evolutionary Theory Need a Rethink?: Yes, Urgently", Nature 2014, vol. 514, s. 161-164, doi:10.1038/514161a.

${ }^{9}$ Por. Gregory A. Wray, Hopi E. Hoekstra, Douglas J. Futuyma, Richard E. Lenski, Trudy F.C. Mackay, Dolph Schluter, and Joan E. Strassmann, „Does Evolutionary Theory Need a Rethink?: No, All Is Well”, Nature 2014, vol. 514, s. 161-164, doi:10.1038/514161a.

${ }^{10}$ Por. Laland, Uller, Feldman, Sterelny, Müller, Moczek, Jablonka, and Odling-Smee, „Does Evolutionary Theory Need a Rethink...”. 
przez osoby przychylne Rozszerzonej Syntezie Ewolucyjnej. Jest to jednak powód, dla którego nie jest jasne, czy podejście to zasługuje na miano nowej syntezy. Czy jest naprawdę nowa, czy też stanowi tylko ulepszenie starego ujęcia?

Architekci Rozszerzonej Syntezy Ewolucyjnej stanowczo podkreślają potrzebę nowej syntezy, lecz zachowują ostrożność co do tego, jak należy ją scharakteryzować. Tak podsumowują to Pigliucci i Müller: ${ }^{11}$

W większej mierze koncepcje zebrane w tym tomie nie dotyczą dynamiki populacji. Rozumiemy ją coraz lepiej, ale wiedza ta nie ulega zasadniczej zmianie w świetle nowych wyników. Większa część nowych badań związana jest raczej z problemami ewolucji, które w ramach Nowoczesnej Syntezy były odsuwane na bok, a obecnie coraz bardziej wysuwają się na pierwszy plan. Problemy te dotyczą konkretnych mechanizmów odpowiedzialnych za duże zmiany formy organizmów, roli plastyczności i czynników środowiskowych lub znaczenia epigenetycznych trybów dziedziczenia. Ta zmiana nacisku ze statystycznej korelacji na przyczynowość mechanistyczną reprezentuje zapewne najważniejszą zmianę w dzisiejszej teorii ewolucji.

Zasadniczo, zgodnie z tymi autorami, o innowacyjności Rozszerzonej Syntezy Ewolucyjnej świadczy to, że otwiera drogę do uznania za kluczowy czynnik ewolucji tego, co stanowiło przedtem niemożliwą do zbadania „czarną skrzynkę". Mimo to, ich zdaniem, nie zmienia to w sposób fundamentalny żadnej wcześniej przyjmowanej podstawowej zasady Nowoczesnej Syntezy.

Jeśli jednak potraktujemy podstawowe zasady Nowoczesnej Syntezy poważnie, dostrzeżemy, że Rozszerzona Synteza Ewolucyjna po cichu, lecz radykalnie, je zmienia. Architekci Rozszerzonej Syntezy Ewolucyjnej najwyraźniej zbyt kurczowo trzymają się dawnych zasad, by szczerze mówić o najbardziej interesujących aspektach swojej propozycji.

\section{Teleonomia i ewolucja}

Aby pojąć, czym Rozszerzona Synteza Ewolucyjna różni się od Nowoczesnej Syntezy, musimy przyjrzeć się koncepcji teleonomii i jej roli w teorii ewolucji.

Od ponad stu lat biologowie zwalczali koncepcję teleologii. Teleologia to

\footnotetext{
${ }^{11}$ Por. Pigliucci and MüLler, ,Elements of an Extended Evolutionary Synthesis...”.
} 
zorientowanie przedmiotów (często organizmów) na cele. Organizmy mają cele, o których świadczą ich zachowania. Biologia stanowi wyjątkowy obszar badań dlatego, że podczas gdy w badaniach skał lub atomów rzadko mówi się o celach, badania w ramach biologii dotyczą niemal wyłącznie celowości.

Podstawą do zrozumienia działania narządów organizmów, podobnie jak genomu, jest celowość. Niewielu ludzi zapytałoby się: „po co istnieje ta góra?” Tymczasem w biologii najbardziej podstawowe pytanie na temat jakiegoś narządu lub układu narządów brzmi: „do czego on służy?”

Zgodnie z arystotelesowskim poglądem na przyczynowość przyczyny celowe (to jest teleologiczne) są równie fundamentalne, jak przyczyny sprawcze. Rozwój nauki w wiekach osiemnastym i dziewiętnastym umniejszył jednak rolę przyczyn teleologicznych, aż w końcu zupełnie wykluczono je z nauki. ${ }^{12} \mathrm{Na}$ przykład Francis Bacon uważał, że poleganie na przyczynowości teleologicznej zbyt mocno powiązało wyjaśnianie przyczynowe z naturą człowieka, przez co trudniej było opisywać rzeczywisty Wszechświat.

W pierwszych latach dziewiętnastego wieku wpływ poglądów Bacona ograniczał się na ogół do fizyki, ale idea ewolucji drogą doboru naturalnego zdawała się wyeliminować teleologię również z biologii. Dobór naturalny nie miał w sobie nic z celowości - dotyczył wyłącznie reprodukcji. Cała ewolucja była więc pozbawiona celu. Jeżeli teleologia nie była potrzebna w fizyce, a obecnie nie jest potrzebna w biologii, to w ogóle wydaje się zbędna.

Wśród biologów cała koncepcja celowości popadła więc w niełaskę. Uważano ją za koncepcję staromodną — relikt, który wkrótce podzieli los alchemii. $\mathrm{Na}$ początku dwudziestego wieku biologowie pieczołowicie unikali, niekiedy popadając w śmieszność, każdego rodzaju języka celowościowego.

Jak pisał Colin Pittendrigh, ${ }^{13}$

\footnotetext{
${ }^{12}$ Por. James C. LeMaster, „Związek między Baconem, teleologią i analogią a doktryną naturalizmu metodologicznego", przeł. Dariusz Sagan, Filozoficzne Aspekty Genezy 2017, t. 14, s. 99-133, http://www.nauka-a-religia.uz.zgora.pl/images/FAG/2017.t.14/art.04.pdf (14.10.2018).

${ }^{13}$ Por. Colin S. Pittendrigh, „Adaptation, Natural Selection, and Behavior”, w: Anne RoE and George Gaylord Simpson (eds.), Behavior and Evolution, Yale University Press, New Haven 1958, s. 390-416.
} 
Przez jakiś czas biologowie byli gotowi mówić, że żółw wyszedł na brzeg $i$ złożył jaja, ale nie chcieli mówić, że wyszedł na brzeg po to, by złożyć jaja [wyróżnienia w oryginale].

Innymi słowy, biologowie starali się nie przypisywać organizmom żadnej celowości w obawie przed uzyskaniem miana teleologów zabarwiających swoje poglądy arystotelesowską ideą przyczynowości. Mimo iż jest oczywiste, że żółwie rzeczywiście przybywają na brzeg w celu złożenia jaj, biologowie woleli nie stwierdzać tego otwarcie.

Chcąc załagodzić tę sytuację, Pittendrigh, ${ }^{14}$ a później Ernst Mayr, ${ }^{15}$ zaproponowali posługiwanie się terminem telonomia, nie zaś teleologia, aby opisać tego rodzaju celowe zachowanie.

Mayr zasugerował, że możemy stosować termin teleonomia w odniesieniu do czegoś, co działa zgodnie z pewnym celem ze względu na jakiś program. Stwierdził on, ${ }^{16}$ że:

Ograniczenie terminu „teleonomiczny” wyłącznie do układów funkcjonujących na zasadzie programu, kodu informacji, wydaje się użyteczne. Teleonomia w biologii odnosi się do „obserwowanej celowości organizmów i ich cech”, jak wyraził się Julian Huxley.

Innymi słowy, jeśli organizmy funkcjonują w zgodzie ze swoim programem genetycznym, to słowo „cel” może odnosić się po prostu do działania programu $\mathrm{w}$ danym organizmie.

Pittendrigh i Mayr wymyślili więc sposób włączenia celowego zachowania i teleologicznych opisów w ramy biologii bez konieczności powoływania się na światopogląd arystotelesowski łączony zazwyczaj z przyczynowością celową.

Mayr martwił się jednak, że ktoś mógłby powiązać, za pośrednictwem teorii ewolucji, nową teleonomię ze starą teleologią. Mianowicie można by usiłować wyjaśnić istnienie celowości kierowanej programem przez odniesienie do syste-

\footnotetext{
${ }^{14}$ Por. Pittendrigh, „Adaptation...”.

${ }^{15}$ Por. Ersnt MAYr, „Cause and Effect in Biology”, Science 1961, vol. 134, s. 1501-1506, doi:10.1126/science.134.3489.1501.

${ }^{16}$ Por. MAYR, „Cause and Effect in Biology...”.
} 
mu teleologicznego (to jest boskiego zamysłu lub czegoś podobnego). Rozwijająca się wówczas Nowoczesna Synteza miała jednak gotową odpowiedź sama ewolucja zrywa wszelkie teleologiczne związki między organizmem a jakąś wyższą zasadą organizacyjną. Ewolucja przebiega na zasadzie losowych lub przypadkowych zmian (czyli zmian nieteleologicznych), nie istnieje więc żaden związek między wytworami ewolucji a jakimiś celami w przyrodzie.

Tak wyraził to Mayr: ${ }^{17}$

Znamy tylko trzy procesy odpowiadające za [zmianę puli genetycznej]: mutacja, fluktuacja częstości genów i zróżnicowana reprodukcja. Pierwsze dwa procesy nie są zorientowane na adaptację. W tym sensie są więc zasadniczo losowe i zwykle nieadaptacyjne, chociaż z rzadka, szczęśliwym trafem, mogą mieć wartość przystosowawczą. Przez „zróżnicowaną reprodukcję” rozumie się stałe, średnio rzecz biorąc, płodzenie większej liczby potomstwa przez osobniki o pewnych cechach genetycznych w porównaniu z osobnikami, które tych konkretnych cech nie mają [...].

Jeśli organizm jest dobrze zaadaptowany, jeżeli wykazuje większe dostosowanie, nie ma to żadnego związku z jakimś celem jego przodków lub z działaniem zewnętrznego bytu, na przykład „Natury” bądź „Boga”, który stworzył lepszy projekt czy plan.

Jak wskazuje Francesca Merlin, ${ }^{18}$ pogląd ten głoszony był nie tylko przez Mayra, lecz przez wszystkich twórców Nowoczesnej Syntezy. Organizmy mają cele, ale nie wybraty ich celowo. Zauważmy, że w powyższym cytacie Mayr otwarcie wyklucza nie tylko wpływ zewnętrznych celów (to jest boskiej teleologii) na ewolucję, lecz również celów wewnętrznych (czyli biologicznych celów przodków).

\section{Unifikacja Rozszerzonej Syntezy Ewolucyjnej i Ewolucyjnej Teleonomii}

Co to wszystko ma wspólnego z Rozszerzoną Syntezą Ewolucyjną? Okazuje się, że całkiem sporo.

Możemy podsumować spojrzenie Nowoczesnej Syntezy na teleonomię następująco:

\footnotetext{
${ }^{17}$ Por. MAYr, „Cause and Effect in Biology...”.

${ }^{18}$ Por. Merlin, „Evolutionary Chance Mutation...”.
} 
1. Za przejawianie przez organizmy celowości odpowiada teleonomia.

2. Ewolucją nie kieruje żaden teleonomiczny czynnik.

Pod wieloma względami Rozszerzona Synteza Ewolucyjna zdaje się jednak bezpośrednio przeczyć temu punktowi widzenia. W kolejnych częściach artykułu przeanalizuję kilka $\mathrm{z}$ nich.

\section{Tryby dziedziczenia}

Jednym z głównych aspektów, w jakich Rozszerzona Synteza Ewolucyjna różni się od Nowoczesnej Syntezy, jest liczba możliwych trybów dziedziczenia w procesie ewolucji. Każdy z tych trybów zdaje się wykazywać w swoim działaniu pewien stopień teleonomii.

Pierwszy tryb dziedziczenia, który poddam analizie, to dziedziczenie nisz. Jest to idea, że organizmy tworzą nisze, które z kolei wywierają ewolucyjny wpływ na organizmy. Innymi słowy, organizmy tworzą środki odgrywające rolę w ich własnej ewolucji.

Co napędza tworzenie nisz? Panuje zgodne przekonanie, że program genetyczny w organizmie dyktuje mu sposób kształtowania własnego środowiska. Wiemy też, że te środowiska działają na korzyść organizmów $i$ ich potomstwa.

$\mathrm{W}$ organizmie istnieje więc program wpływający na jego ewolucję. Bezpośrednio przeczy to spostrzeżeniu Mayra, że ,jeśli organizm jest dobrze zaadaptowany, jeżeli wykazuje większe dostosowanie, nie ma to żadnego związku z jakimś celem jego przodków lub z działaniem zewnętrznego bytu”. Jednak zgodnie z ideą dziedziczenia nisz przyczyna adaptacji organizmu do środowiska są właśnie cele przodków organizmu. Znaczy to, że w przypadku dziedziczenia nisz ewolucja jest przynajmniej częściowo kierowana teleonomią.

Podobny przypadek stanowi dobór płciowy. Organizmy, podlegając swoim wewnętrznym programom, wybierają partnerów, z którymi spłodzą najzdrowsze potomstwo. Ich wewnętrzne programy genetyczne (czyli teleonomia organizmów) kierują więc własnymi ewolucyjnymi wytworami. ${ }^{19}$ Dobór płciowy

\footnotetext{
${ }^{19}$ Można wskazywać, że koncepcja doboru płciowego zawsze zajmowała ważne miejsce $\mathrm{w}$ teorii ewolucji, nawet w czasie formułowania Nowoczesnej Syntezy. To prawda. Nieczęsto
} 
działa dlatego, że końcowe wytwory ewolucji są dokładnie takie, jakich poszukuje program genetyczny. Organizmy wybierają zdrowych partnerów (dobór płciowy) w celu (teleonomia) spłodzenia zdrowego potomstwa (Ewolucyjna Teleonomia).

Ma to także miejsce w przypadku dziedziczenia epigenetycznego. Organizmy potrafią modulować swoje geny za pośrednictwem oddziaływań epigenetycznych, a dokonują tego dzięki swoim wewnętrznym programom. Tak więc wyjściowe modyfikacje w jednym pokoleniu, które kierowane są programem teleonomicznym, bezpośrednio wpływają na wytwory ewolucyjne w pokoleniu następnym.

\section{Biologia rozwoju}

W myśl Rozszerzonej Syntezy Ewolucyjnej istotną rolę w ewolucji odgrywa biologia rozwoju. Ściślej rzecz biorąc, szlaki rozwojowe leżące u podstaw ontogenezy kanalizują skutki ewolucji genetycznej. Innymi słowy, organizmy rozwijają się w taki sposób, by obrócić na swoją korzyść występujące w nich mutacje. Posiadają mechanizmy powodujące, że potencjalnie przypadkowe mutacje nie zakłócają spójności procesu rozwoju.

Na przykład podczas rozwoju kości chondrocyty wydzielają czynniki stymulujące formowanie naczyń krwionośnych. ${ }^{20}$ Naczynia krwionośne i struktury kostne nie muszą być więc zakodowane w genomie osobno. Są ze sobą powiązane w taki sposób, że zmiany struktur kostnych automatycznie powodują odpowiednią zmianę w formowaniu naczyń krwionośnych. Gwarantuje to, że kości o nowym kształcie będą należycie unaczynione.

Istnieje więc program (teleonomia), który częściowo kieruje ewolucją organizmu, dając gwarancję, że pewne zmiany będą odpowiadać innym.

uwzględniano lub w ogóle nie dostrzegano jednak tego, że natura doboru płciowego podważa, a nawet bezpośrednio przeczy naturze selekcji w ujęciu tej teorii. Coraz większy nacisk na dobór płciowy wskazuje na kolejne wewnętrzne niespójności w sposobie, w jaki rozumiano i stosowano terminy i idee w ramach Nowoczesnej Syntezy. Oznacza to również, że leżące u jej podstaw zasady unifikujące są w mniejszym stopniu trafne (i mają mniejszą siłę unifikacji) niż dotąd uważano.

${ }^{20}$ Por. Kishor K. Sivaraj and Ralf H. Adams, „Blood Vessel Formation and Function in Bone”, Development 2016, vol. 143, s. 2706-2715, doi:10.1242/dev.136861. 


\section{Ewoluowalność}

Inny ważny obszar badań w ramach Rozszerzonej Syntezy Ewolucyjnej dotyczy ewoluowalności. Zasadniczo jest to idea, że z różnymi cechami genetycznymi organizmu związane są różne odległości edycyjne w stosunku do genomu jego przodka. Odległość edycyjna warunkowana jest jednak nie tylko samą liczbą par zasad wymagających zmian, ale również mechanizmami zmiany obecnymi w organizmie. Gdy mechanizmy zmiany (to jest programy lub teleonomia kierujące powstawaniem mutacji w organizmie) są zbieżne ze szlakami ewoluowalności (czyli z cechami podlegającymi selekcji), organizm wykazuje bardzo bezpośredni typ Ewolucyjnej Teleonomii.

Ta gałąź Rozszerzonej Syntezy Ewolucyjnej odpowiada (zarówno jeśli chodzi o zwolenników, jak i idee) projektowi, który zyskał miano „trzeciej drogi”. ${ }^{21}$ James Shapiro, ${ }^{22}$ Lynn Caporale ${ }^{23}$ i Denis Noble ${ }^{24}$ wskazują, że wiele układów w organizmie może kierować ewolucją konkretnych genów. Te systemy ewoluowalności zakodowane są $\mathrm{w}$ genomie i ukierunkowywane przez produkty genów, zaś same wywołują skutki korzystne dla ewolucji potomstwa. Pasują one do koncepcji Ewolucyjnej Teleonomii pod każdym względem.

\section{Teleonomia w Rozszerzonej Syntezie Ewolucyjnej}

Jak widać, Ewolucyjna Teleonomia odgrywa kluczową, unifikującą rolę w niemal każdym aspekcie Rozszerzonej Syntezy Ewolucyjnej. ${ }^{25}$ Ponadto sama

\footnotetext{
${ }^{21}$ Wykaz zwolenników „trzeciej drogi” znajduje się na następującej stronie: http://www.the thirdwayofevolution.com/people (15.10.2018).

${ }^{22}$ Por. James A. Shapiro, Evolution: A View from the 21st Century, FT Press Science, Upper Saddle River, New Jersey 2011, doi:10.1093/gbe/evs008.

${ }^{23}$ Por. Lynn H. Caporale, The Implicit Genome, Oxford University Press, New York 2006.

${ }^{24}$ Por. Denis Noble, „Evolution Beyond Neo-Darwinism: A New Conceptual Framework”, The Journal of Experimental Biology 2015, vol. 218, s. 7-13, doi:10.1242/jeb.106310.

${ }^{25}$ Niektóre aspekty Rozszerzonej Syntezy Ewolucyjnej, takie jak „dwustronna przyczynowość” i „perspektywa organizmocentryczna”, są nieco bardziej mgliste, jest jednak jasne, że koncepcja Ewolucyjnej Teleonomii dobrze z nimi współgra. Ewolucyjna Teleonomia dotyczy szczególnie przyczynowości dwustronnej (organizmy kierujące własną ewolucją) i trudno znaleźć coś bardziej organizmocentrycznego niż przekonanie, że organizm sam stanowi jeden z czynników
} 
idea teleonomii bardziej naturalnie łączy się z innymi sposobami analizy zjawisk biologicznych. W niemal każdym innym aspekcie biologii jako zasadę heurystyczną w próbie zrozumienia, jak działają układy biologiczne, przyjmuje się założenie funkcjonalności. To teleonomiczne założenie zostało wyeliminowane w okresie panowania Nowoczesnej Syntezy, ale dalsze odkrycia w dziedzinie teorii ewolucji, poczynione przez ostatnie kilkadziesiąt lat, wskazują, że Ewolucyjna Teleonomia powinna odzyskać centralne miejsce w ewolucjonistycznym stylu myślenia.

\section{Jak koncepcja Ewolucyjnej Teleonomii wspomaga rozumowanie w biologii}

We Wprowadzeniu podkreśliłem znaczenie zasad unifikujących $\mathrm{w}$ danej dyscyplinie. Ludzie muszą mieć przecież możliwość rozumowania i odnajdywania związków logicznych nawet wówczas, gdy nie znają wszystkich faktów. Rozwój teorii ma więc najwyższą wagę, ponieważ dostarcza wyjaśnienia, dzięki któremu uzyskujemy informacje niemożliwe do zdobycia bezpośrednio. Nowoczesna Synteza to nie tylko etykietka, lecz także sposób dostarczania faktów wykraczających poza to, co można wyczytać w danych empirycznych. Jeśli synteza jest bardzo bliska prawdy o świecie, może stanowić ogromny krok naprzód. Jeżeli jest jednak odwrotnie, to - często bez ostrzeżenia - sprowadzi nas na manowce w ważnych obszarach badań.

Doskonałym przykładem tej drugiej sytuacji jest niedawno opublikowany artykuł Dana Graura. ${ }^{26} \mathrm{~W}$ artykule tym połączył on ze sobą różne zbiory danych i równania genetyki populacyjnej w celu ustalenia, jaka część ludzkiego genomu jest funkcjonalna. ${ }^{27}$ Aby tego dokonać, Graur musiał oszacować tempo

\footnotetext{
przyczynowych w ewolucji.

${ }^{26}$ Por. Dan Graur, „An Upper Limit on the Functional Fraction of the Human Genome”, Genome Biology and Evolution 2017, vol. 9, s. 1880-1885, doi:10.1093/gbe/evx121.

${ }^{27}$ Recenzent niniejszego artykułu żartobliwie zauważył, że być może, wzorując się na prak tykach naukowców z początków dwudziestego wieku, o jakich pisał Pittendrigh (por. PitTendRigh, „Adaptation...”. W części zatytułowanej „Teleonomia i ewolucja” przytoczyłem jego przykład z żółwiem), nie powinniśmy mówić, że Graur połączył ze sobą zbiory danych $w$ celu ustalenia, jaka część ludzkiego genomu jest funkcjonalna, lecz że połączył zbiory danych $i$ następnie zidentyfikował funkcjonalną część genomu człowieka. Jak wskazał J. Scott Turner, celowość kryje się
} 
zachodzenia szkodliwych mutacji na parę zasad w genomie. Jak to zrobił?

Przede wszystkim wybrał tempo zachodzenia mutacji, opierając się na danych Aylwyna Scally'ego, według którego tempo to wynosi $1.0 \times 10^{-8} .{ }^{28} \mathrm{Na}-$ stępnie, aby oszacować ułamek mutacji, które są szkodliwe, podzielił mutacje na trzy kategorie: mutacje synonimiczne (czyli takie, które nie zmieniają sekwencji aminokwasów), mutacje zmiany sensu (zmieniające jeden aminokwas) i mutacje nonsensowne (tworzące przedwczesny kodon stop, który uniemożliwia ekspresję całego genu).

Graur argumentuje, że mutacje synonimiczne nie mają wpływu na selekcję, a zatem kategorycznie należy uznać je za nieszkodliwe, natomiast mutacje nonsensowne wpływają na selekcję, a więc bezsprzecznie należy je zaliczyć do klasy mutacji szkodliwych.

W ten sposób otrzymujemy granice dolną i górną ułamka szkodliwych mutacji, wynoszące między $4 \%$ a $76 \%$. Tak więc rzeczywista wartość ułamka mutacji szkodliwych w tym dość dużym zakresie determinowana jest przez częstość występowania szkodliwych mutacji zmiany sensu. Ze względu na cele mojej argumentacji nie poddam krytyce dotychczas omówionych założeń i szacunków Graura i uznam je za poprawne.

Pytanie brzmi: jaki procent mutacji zmiany sensu jest szkodliwy? To tutaj właśnie do gry wchodzą zasady unifikujące Nowoczesnej Syntezy. Graur łączy ze sobą dwa różne zbiory danych statystycznych, co można by uznać za zabieg zasadny, jeżeli Nowoczesna Synteza jest ujęciem prawdziwym. Jeśli jednak nie jest ona ujęciem prawdziwym, to tych zbiorów danych nie można łączyć ze sobą tak, jak zrobił to Graur. Przyjmę, że same te poszczególne zbiory danych statystycznych są prawidłowe.

Pierwszy zbiór danych statystycznych to dane wskazujące, jaki ułamek wszystkich możliwych mutacji zmiany sensu jest szkodliwy. Przy tej okazji Graur posłużył się szacunkiem Mischy Soskine i Dana Tawfika, zgodnie z któ-

za niemal każdą aktywnością organizmów biologicznych (por. J. Scott Turner, Purpose and Desire, HarperOne, New York 2017).

${ }^{28}$ Por. Aylwyn Scally, „The Mutation Rate in Human Evolution and Demographic Inference", Current Opinion in Genetics and Development 2016, vol. 41, s. 36-43, doi:10.1016/j.gde. 2016.07.008. 
rym pośród całkowitej liczby możliwych mutacji zmiany sensu te szkodliwe stanowią $40 \% .{ }^{29}$ Następnie odnosi on to do liczby mutacji zmiany sensu w ludzkim genomie, którą oszacowano na $72 \%$ wszystkich mutacji.

Czy te liczby da się jednak połączyć w ten sposób?

Liczba uzyskana przez Soskine i Tawfika reprezentuje ułamek wszystkich możliwych mutacji zmiany sensu, które są szkodliwe. ${ }^{30} \mathrm{Czy}$ jednak zbiór mutacji zmiany sensu, które rzeczywiście zachodza w genomie, jest tożsamy ze zbiorem wszystkich możliwych mutacji tego rodzaju? Jeżeli Nowoczesna Synteza jest ujęciem prawdziwym, to możemy przynajmniej powiedzieć, że zakres rzeczywiście zachodzących mutacji nie powinien preferencyjnie wchodzić w zakres wszystkich możliwych mutacji zmiany sensu lub znajdować się poza nim. W takim wypadku moglibyśmy utożsamić procentowy ułamek wszystkich możliwych mutacji zmiany sensu z tymi, które rzeczywiście zachodzą. Jeżeli przyjmiemy, że genom mutuje wyłącznie przypadkowo (to jest nieteleonomicznie), to można stworzyć sensowny model, w którym brak preferencji dla mutacji szkodliwych i nieszkodliwych stanowiłby próbkę z tego zbioru.

Jeśli jednak genom jest w jakimś sensie aktywny (czyli teleonomiczny) w wyborze mutacji, to obecnie nie istnieje żaden sposób, w jaki dałoby się połączyć ze sobą te dwa zbiory danych. Jak wykazałem w poprzednich częściach tego artykułu, istnieje wiele świadectw na to, że ewolucja genetyczna jest przynajmniej częściowo teleonomiczna. Nie da się zatem połączyć tych zbiorów danych. ${ }^{31}$

Według recenzenta niniejszego artykułu założenie Graura, zgodnie z którym mutacje synonimiczne są neutralne, również jest problematyczne. Wyniki badań dają bowiem poważne powody do uznania, że miejsca, w których następują mutacje synonimiczne, podlegają selekcji. Problem, czy mutacje synonimiczne

\footnotetext{
${ }^{29}$ Por. Misha Soskine and Dan S. TAwFIK, ,Mutational Effects and the Evolution of New Protein Functions”, Nature Reviews Genetics 2010, vol. 11, s. 572-582, doi:10.1038/nrg2808.

${ }^{30}$ Por. Soskine and TAWFIK, „Mutational Effects...”.

${ }^{31} \mathrm{Z}$ artykułem Graura wiąże się wiele innych problemów, nie wyłączając kwestii sposobu, w jaki technologia kompensuje niezbędny wskaźnik zastępowalności pokoleń w przypadku człowieka. Omawiany w artykule problem wybrałem jednak przez wzgląd na jego szczególny zwią zek z zasadami unifikującymi Nowoczesnej Syntezy.
} 
wpływają na selekcję, stanowi interesujący temat sam w sobie i ma on także duże znaczenie dla koncepcji Ewolucyjnej Teleonomii. Zespół J.V. Chamary'ego ${ }^{32}$ wykazał, że - w związku z takimi zjawiskami jak splicing intronów i stabilność mRNA - mutacje synonimiczne rzeczywiście wywierają wpływ na substytucję. Niemniej w artykule tego zespołu da się dostrzec takie same problemy jak w artykule Graura. Mianowicie przyjęto w nim, że losowe rozkłady mutacji stanowią dostatecznie dobre przybliżenie do rzeczywistych rozkładów mutacji, a jest to zgodne z założeniem, że mutacje nie są ukierunkowane na uzyskanie jakiegoś konkretnego, korzystnego skutku. Zespół Chamary’ego ${ }^{33}$ wykazał, że w genomie istnieją miejsca, które wydają się niezmienne, i założyl, że ma to związek z presją selekcyjną. Tymczasem można to przypisać również temu, że organizmy rzadziej doświadczają mutacji w regionach, w których ich skutki są potencjalnie szkodliwe. Autorzy w ogóle nie wzięli pod uwagę poglądu, że sam rozkład mutacji może być kierowany przez wewnętrzne mechanizmy.

Widać więc, że zasady unifikujące nie są stosowane jedynie w edukacji (aby nauczyć ludzi przedmiotu, który studiują), ale bezpośrednio wykorzystuje się je również w rozumowaniach dotyczących badanego przedmiotu. Koncepcja Ewolucyjnej Teleonomii może okazać się użyteczna chociażby dlatego, że redaktorzy i recenzenci będą wiedzieli, jak odnieść się do klasy rozważań, które mogą zostać podjęte przez badaczy w ich publikacjach. „Czy rozważyłeś wpływ, jaki koncepcja Ewolucyjnej Teleonomii mogłaby wywrzeć na twoje wyniki i szacunki?"

Koncepcja Ewolucyjnej Teleonomii wskazuje ponadto potencjalnie użyteczne kierunki badań ewolucyjnych. Badania te bardzo długo były zdominowane przez ujęcie Nowoczesnej Syntezy, ale wiele obszarów dojrzało już do ponownej analizy z punktu widzenia Ewolucyjnej Teleonomii. Termin ten zapewnia zunifikowany sposób mówienia o tych przedsięwzięciach i ich pojmowania. Pytanie: „w jakim stopniu organizm sam napędza swoją ewolucję?” jest ważne, ale przez ponad sto lat było pomijane. Ewolucyjna Teleonomia stanowi zunifikowaną ramę dla znajdowania odpowiedzi na to i podobne pytania.

\footnotetext{
${ }^{32}$ Por. J.V. Chamary, Joanna L. Parmley, and Laurence D. Hurst, „Hearing Silence: NonNeutral Evolution at Synonymous Sites in Mammals", Nature Reviews Genetics 2006, vol. 7, s. 98-108, doi:10.1038/nrg1770.

${ }^{33}$ Por. Chamary, Parmley, and Hurst, „Hearing Silence...”.
} 
Koncepcja Ewolucyjnej Teleonomii normalizuje również sposób wnioskowania w naukach biologicznych. Na przykład w dziedzinie biologii systemowej na ogół wychodzi się od założenia funkcjonalności każdego badanego układu. Nie oznacza to konieczności wyciągnięcia wniosku, że wszystkie układy są funkcjonalne. Wyjściowy sposób wnioskowania polega na przyjęciu, że dany układ biologiczny prawdopodobnie jest funkcjonalny, chyba że znajdziemy konkretne powody do uznania, że to nieprawda. Odnosi się to do wszystkich problemów, którymi zajmują się nauki biologiczne. Zakłada się, że socjologiczna struktura organizmów, ich makroskopowa morfologia, narządy, struktura komórkowa i tak dalej mają przynosić korzyść organizmowi lub gatunkowi jako całości, o ile coś temu założeniu nie zaprzeczy. Jeżeli nie znamy funkcji danego układu, to po prostu klasyfikuje się go jako układ o nieznanej funkcji.

Wyjątek stanowią układy ewolucyjne, a przyczyną tego stanu rzeczy jest wpływ Nowoczesnej Syntezy. Koncepcja Ewolucyjnej Teleonomii jednoczy teorię ewolucji z pozostałymi naukami biologicznymi. Nie mówi ona, że wszystkie procesy ewolucyjne są z konieczności funkcjonalne, lecz że nie możemy wykluczyć ich funkcjonalności, jeśli nie dysponujemy konkretnymi danymi empirycznymi. Bez wątpienia nie można też założyć ich niefunkcjonalności, jak uczynił to Graur, kiedy twórczo połączył ze sobą różne zbiory danych.

\section{Zakończenie}

Zasady unifikujące związane $\mathrm{z}$ danym przedmiotem badań pełnią różne ważne funkcje. W wielkim stopniu wspomagają edukację i intuicję, a także stanowią podstawę dla wnioskowań opartych na niekompletnych danych. W dwudziestym wieku Nowoczesna Synteza dominowała jako zasada unifikująca teorii ewolucji biologicznej. Koncentrowała się ona na idei, że ewolucja przydarza się organizmowi i że sam organizm nie wywiera żadnego istotnego wpływu przyczynowego na własną ewolucję. Zwolennicy Rozszerzonej Syntezy Ewolucyjnej głoszą, że sformułowali nowy sposób patrzenia na ewolucję. Nie stworzyli jednak zbioru zasad unifikujących dla biologów. Zaproponowałem koncepcję Ewolucyjnej Teleonomii - ideę, zgodnie z którą organizmy mogą aktywnie wpływać na własną ewolucję na każdym poziomie - jako nową podstawową zasadę biologii ewolucyjnej. Ewolucyjna Teleonomia jednoczy wiele niezależnych te- 
matów podejmowanych w ramach Rozszerzonej Syntezy Ewolucyjnej pod jedną, zrozumiałą etykietką.

Jak wskazałem, zasady unifikujące mają rzeczywisty wpływ na sposób, w jaki fakty biologiczne są ujmowane i stosowane w badaniach biologicznych, zaś poleganie na błędnych zasadach prowadzi do niepoprawnych wyników.

Jonathan Bartlett

\section{Bibliografia}

Bromнam Lindell, „Does Nothing in Evolution Make Sense Except in the Light of Population Genetics?", Biology and Philosophy 2009, vol. 24, s. 387-403, doi:10.1007/s10539008-9146-6.

Caporale Lynn H., The Implicit Genome, Oxford University Press, New York 2006.

Chamary J.V., Parmley Joanna L., and Hurst Laurence D., „Hearing Silence: Non-Neutral Evolution at Synonymous Sites in Mammals", Nature Reviews Genetics 2006, vol. 7, s. 98108, doi:10.1038/nrg1770.

Futuyma Douglas J., „Can Modern Evolutionary Theory Explain Macroevolution?”, w: SeRRelli and GonTIER (eds.), Macroevolution..., s. 29-86, doi:10.1007/978-3-319-1504512 .

Graur Dan, „An Upper Limit on the Functional Fraction of the Human Genome”, Genome Biology and Evolution 2017, vol. 9, s. 1880-1885, doi:10.1093/gbe/evx121.

Kimura Motoo, The Neutral Theory of Molecular Evolution, Cambridge University Press, Cambridge 1983.

Laland Kevin N., Uller Tobias, Feldman Marc W., Sterelny Kim, Müller Gerd B., Moczek Armin, Jablonka Eva, and Oduing-Smee John, „Does Evolutionary Theory Need a Rethink?: Yes, Urgently”, Nature 2014, vol. 514, s. 161-164, doi:10.1038/514161a.

LeMaster James C., „Związek między Baconem, teleologią i analogią a doktryną naturalizmu metodologicznego", przeł. Dariusz Sagan, Filozoficzne Aspekty Genezy 2017, t. 14, s. 99-133, http://www.nauka-a-religia.uz.zgora.pl/images/FAG/2017.t.14/art.04.pdf (14.10. 2018).

MAYr Ersnt, „Cause and Effect in Biology”, Science 1961, vol. 134, s. 1501-1506, doi:10. 1126/science.134.3489.1501.

MerLin Francesca, „Evolutionary Chance Mutation: A Defense of the Modern Synthesis' Consensus View”, Philosophy and Theory in Biology 2010, vol. 2, e103, doi:10.3998/ptb. 6959004.0002 .003$. 
Noble Denis, „Evolution Beyond Neo-Darwinism: A New Conceptual Framework”, The Journal of Experimental Biology 2015, vol. 218, s. 7-13, doi:10.1242/jeb.106310.

Pigliucci Massimo and Müller Gerd B., „Elements of an Extended Evolutionary Synthesis", w: Pigliucci and Müller (eds.), Evolution, the Extended Synthesis..., s. 3-17, doi: 10.7551/mitpress/9780262513678.003.0001.

Pigliucci Massimo and Müller Gerd B. (eds.), Evolution, the Extended Synthesis, MIT Press, Cambridge 2010, doi:10.7551/mitpress/9780262513678.001.0001.

Pittendrigh Colin S., „Adaptation, Natural Selection, and Behavior”, w: Roe and Simpson (eds.), Behavior and Evolution..., s. 390-416.

Roe Anne and Simpson George Gaylord (eds.), Behavior and Evolution, Yale University Press, New Haven 1958.

Scally Aylwyn, „The Mutation Rate in Human Evolution and Demographic Inference”, Current Opinion in Genetics and Development 2016, vol. 41, s. 36-43, doi:10.1016/j.gde. 2016.07.008.

Serrelli Emanuele and Gontier Nathalie (eds.), Macroevolution: Explanation, Interpretation and Evidence, Springer, New York 2015.

Shapiro James A., Evolution: A View from the 21st Century, FT Press Science, Upper Saddle River, New Jersey 2011, doi:10.1093/gbe/evs008.

Sivaraj Kishor K. and Adams Ralf H., „Blood Vessel Formation and Function in Bone”, Development 2016, vol. 143, s. 2706-2715, doi:10.1242/dev.136861.

Soskine Misha and TAwFik Dan S., „Mutational Effects and the Evolution of New Protein Functions”, Nature Reviews Genetics 2010, vol. 11, s. 572-582, doi:10.1038/nrg2808.

Turner J. Scott, Purpose and Desire, HarperOne, New York 2017.

Wray Gregory A., Hoekstra Hopi E., Futuyma Douglas J., Lenski Richard E., Mackay Trudy F.C., Schluter Dolph, and Strassmann Joan E., „Does Evolutionary Theory Need a Rethink?: No, All Is Well”, Nature 2014, vol. 514, s. 161-164, doi:10.1038/514161a.

\section{Ewolucyjna Teleonomia jako zasada unifikująca Rozszerzonej Syntezy Ewolucyjnej}

\section{Streszczenie}

Wielu ludzi nie docenia wpływu wywieranego przez zasady unifikujące na badania biologiczne. Zasady te mają dostarczać upraszczających założeń w przypadku złożonych problemów, dzięki czemu można te problemy skutecznie rozwiązywać przy użyciu dostępnych narzędzi. Błędne założenia upraszczające mogą jednak prowadzić do nieprawidłowego opisu problemów, a więc i do bezpodstawnych wniosków. Zasady unifikujące Nowoczesnej Syntezy biologii ewolucyjnej są obecnie podważane przez Rozszerzoną Syntezę Ewolucyj- 
ną. Ta ostatnia, jak dotąd, nie zapewniła jednak własnych zasad unifikujących, przez co wielu naukowców wątpi, czy rzeczywiście stanowi ona oryginalną syntezę biologii ewolucyjnej. W niniejszym artykule za zasadę unifikującą Rozszerzonej Syntezy Ewolucyjnej uznaję koncepcję ewolucyjnej teleonomii (jest to koncepcja Ernsta Mayra zastosowana do samych procesów ewolucyjnych). Dostarczę ponadto konkretnych przykładów pokazujących, że współczesne badania, biorąc za podstawę zasady unifikujące Nowoczesnej Syntezy, prowadzą w ślepą uliczkę. Można temu zaradzić dzięki przyjęciu Rozszerzonej Syntezy Ewolucyjnej wraz z ewolucyjną teleonomią jako zasadą unifikującą.

Slowa kluczowe: Ewolucyjna Teleonomia, Nowoczesna Synteza, Rozszerzona Synteza Ewolucyjna, zasada unifikująca, teoria ewolucji, teleologia, rozumowanie w biologii.

\section{Evolutionary Teleonomy as a Unifying Principle for the Extended Evolutionary Synthesis}

\section{Summary}

Many people underestimate the effect that unifying principles have on the study of biology. Unifying principles are used to provide simplifying assumptions to complex problems, which allow them to be effectively tackled by the tools at hand. However, erroneous unifying principles will generate simplifying assumptions that lead towards mischaracterizations of problems which inevitably lead to invalid conclusions. The unifying principles of the current Modern Synthesis of evolution are presently being challenged by the Extended Evolutionary Synthesis. However, the Extended Evolutionary Synthesis has so far failed to provide unifying principles of its own, which has caused many to question whether or not the Extended Evolutionary Synthesis is indeed a unique synthesis of evolutionary biology. Here, the concept of evolutionary teleonomy (Ernst Mayr's concept of teleonomy applied to evolutionary processes themselves) is identified as a unifying principle of the Extended Evolutionary Synthesis. Additionally, specific examples are provided where modern research has been led astray by the unifying principles of the Modern Synthesis which would have been corrected by applying the Extended Evolutionary Synthesis with the unifying principle of evolutionary teleonomy.

Keywords: Evolutionary Teleonomy, Modern Synthesis, Extended Evolutionary Synthesis, unifying principle, evolutionary theory, teleology, biological reasoning. 